\title{
Mengungkap Pemahaman Konsep Listrik Dinamis di Sekolah Berbasis Kemaritiman
}

\author{
Doni Setiawan \\ Program Studi Magister Pendidikan Fisika, Pascasarjana Universitas Negeri Semarang \\ JI. Kelud Utara III, Semarang 50237 \\ E-mail: donisukisno@gmail.com
}

\begin{abstract}
Abstrak
Penelitian ini bertujuan untuk mendeskripsikan pemahaman konsep siswa pada meteri listrik dinamis di sekolah berbasis kemaritiman di kota Tegal. Penelitian dilakukan melalui test diagnostik empat tahap. Konsep listrik dinamis mencakup : Kuat arus listrik, beda potensial, rangkaian seri-paralel, daya listrik, dan hukum 1 Kirchoff. Penelitian dilakukan di SMA Nahdlatul Ulama kota Tegal sebagai sampel sekolah berbasis kemaritiman di kota Tegal pada tahun ajaran 2018/2019. Sampel yang digunakan dalam penelitian yaitu kelas XII IPA SMA Nahdlatul Ulama kota Tegal yang berjumlah 29 siswa. Tahapan penelitian meliputi (1) Mengkaji referensi dan jurnal terkait penelitian pemahaman konsep; (2) Mengkaji silabus untuk memperoleh miskonsepsi pada materi fisika bab listrik dinamis; (3) Merancang instrumen soal bentuk four tier test yang dapat mendiagnosis miskonsepsi siswa; (5) Validasi oleh ahli yakni dengan dosen; (6) Uji coba instrumen untuk menentukan validitas, reliabilitas, taraf kesukaran dan daya pembeda soal; (7) Uji miskonsepsi siswa yang dilakukan kepada siswa kelas XII IPA SMA Nahdlatul Ulama. Hasil analisis data diperoleh deskripsi pemahaman siswa yang dapat dikategorikan memahami konsep, miskonsepsi, tidak paham konsep dan error. Miskonsepsi paling dominan yaitu daya listrik yang terdisipasi pada rangkaian hanya dipengaruhi oleh besarnya sumber tegangan (baterai). Penambahan dan pengubahan susunan hambatan rangkaian tidak berpengaruh pada besarnya daya yang terdisipasi pada rangkaian. Miskonsepsi siswa ini dipengaruhi oleh intuisi kehidupan sehari-hari.
\end{abstract}

Kata kunci: Pemahaman konsep, four-tier test, kemaritiman

\begin{abstract}
This study aims to describe the understanding of students' concepts on dynamic electric metrics in maritime-based schools in the city of Tegal. The study was conducted through a four-stage diagnostic test. The concept of dynamic electricity includes: Electric current strength, potential difference, series-parallel circuit, electric power, and Kirchoff's 1 law. The study was conducted at Tegal Nahdlatul Ulama High School as a sample of maritime-based schools in Tegal in the 2018/2019 school year. The sample used in the study was 29 students of class XII IPA Nahdlatul Ulama High School in Tegal city. The stages of research include (1) Reviewing references and journals related to understanding concept research; (2) Reviewing the syllabus to obtain misconceptions in the material of dynamic electric chapter physics; (3) Designing a question instrument in the form of a four tier test that can diagnose student misconceptions; (5) Validation by experts, namely with lecturers; (6) Test instruments to determine validity, reliability, degree of difficulty and differentiation of questions; (7) Test of student misconceptions carried out to students of class XII IPA at Nahdlatul Ulama High School. The results of data analysis obtained a description of students' understanding which could be categorized as understanding concepts, misconceptions, not understanding concepts and errors.
\end{abstract}

Keywords: Concept understanding, four-tier test, maritime

\section{PENDAHULUAN}

Indonesia merupakan salah satu negara kepulauan terbesar di dunia. la memiliki sekitar
13.000 pulau dengan garis panjang pantai kurang lebih $99.093 \mathrm{~km}$ yang juga merupakan terpanjang di dunia. Dari sudut pandang geopolitik dan ekonomi, kepulauan Indonesia dianggap memiliki posisi yang strategis karena 
berada diantara bentangan benua Asia dan Australia dan di perlintasan samudera hindia dan pasifik. Oleh karenanya, kepulauan nusantara tidak hanya memiliki budaya dan peradaban maritim yang kuat, diantaranya ditandai dengan kemunculan berbagai kekuatan politik dan ekonomi berbasis maritim, tetapi juga sejarah panjang maritim dan berbagai peninggalannya yang luar biasa kaya.

SMA Nahdlatul Ulama kota Tegal merupakan salah satu sekolah menengah atas di kota Tegal dengan rintisan kurikulum berbasis kemaritiman. Peralihan kurikulum SMA Nahdlatul Ulama menjadi sekolah berbasis kemaritiman menjadikan adanya penyisipan pembelajaran terkait kemaritiman dalam setiap aspek kompetensi dasar yang diajarkan. Hal ini tentunya berpengaruh terhadap proses pembelajaran dikelas yang menyisipkan materi terkait kemaritiman khususnya dalam mata pelajaran fisika yang berpengaruh terhadap pemahaman konsep siswa.

Pemahaman konsep siswa yang kurang baik salah satunya dapat disebabkan oleh adanya miskonsepsi. Berdasarkan studi literatur, cukup banyak siswa yang mengalami miskonsepsi dalam pembelajaran fisika, seperti pada konsep mekanika, listrik dan magnet, optik dan gelombang, suhu dan kalor, serta fisika modern (Turgut, U., et al, 2011).

Salah satu cara untuk menggali dan mengidentifikasi miskonsepsi siswa adalah melalui tes diagnostik. Penggunaan tes diagnostik dapat dilakukan di awal maupun akhir pembelajaran untuk mengungkap pemahaman konsep siswa (Mardapi, 2012).

Bentuk tes diagnostik miskonsepsi yang telah dikembangkan saat ini adalah tes diagnostik miskonsepsi empat jenjang (fourtier). Pengembangan tes diagnostik miskonsepsi berformat four-tier dilakukan oleh Fariyani (2017) untuk mengungkap miskonsepsi fisika pada materi optik geometri dan diperoleh hasil instrumen yang dikembangkan valid dan dapat mengungkap miskonsepsi siswa kelas $X$ materi optik geometri. Fratiwi (2017) mengembangkan instrumen tes diagnostik miskonsepsi four-tier untuk mengungkap miskonsepsi siswa pada materi hukum Newton dan instrumen yang dihasilkan valid.

Materi listrik arus searah merupakan salah satu materi yang dianggap sulit oleh siswa, yamg mana tingkat penguasaan konsep pada materi tersebut masih rendah (Papadimitriou, 2012).

\section{METODE/EKSPERIMEN}

Penelitian ini dilaksankan pada bulan September 2018 di SMA Nahdlatul Ulama kota Tegal sebagai sekolah rintisan berbasis kemaritiman pada tahun ajaran 2018/2019. Populasi dalam penelitian ini yaitu seluruh siswa SMA Nahdlatul Ulama kota Tegal yang berjumlah 162 siswa, sedangkan sampel yang digunakan dalam penelitian yaitu kelas XII IPA SMA Nahdlatul Ulama kota Tegal yang berjumlah 29 siswa. Kurikulum yang digunakan adalah kurikulum 2013 revisi yang berbasis kemaritiman.

Variabel yang diteliti yaitu pemahaman konsep siswa terhadap materi listrik dinamis pada sub materi rangkaian listrik sederhana terhadap pengaruh kurikulum berbasis kemaritiman yang diimplementasikan pada penyisipan materi terkait kemaritiman pada rencana pelaksanaan pembelajaran (RPP) yang digunakan.

Penyisipan muatan kemaritiman berupa implementasi rangkaian listrik pada sistem perkapalan dan sistem pembangkit listrik tenaga ombak. Hasil dari penelitian mengenai pemahaman konsep siswa ini diperoleh siswa yang dikategorikan miskonsepsi, tidak paham konsep, paham konsep, paham sebagian, dan tidak dapat dikodekan.

Jenis penelitian ini termasuk dalam penelitian deskriptif kualitatif. Desain dan laur penelitian seperti Gambar 1. 


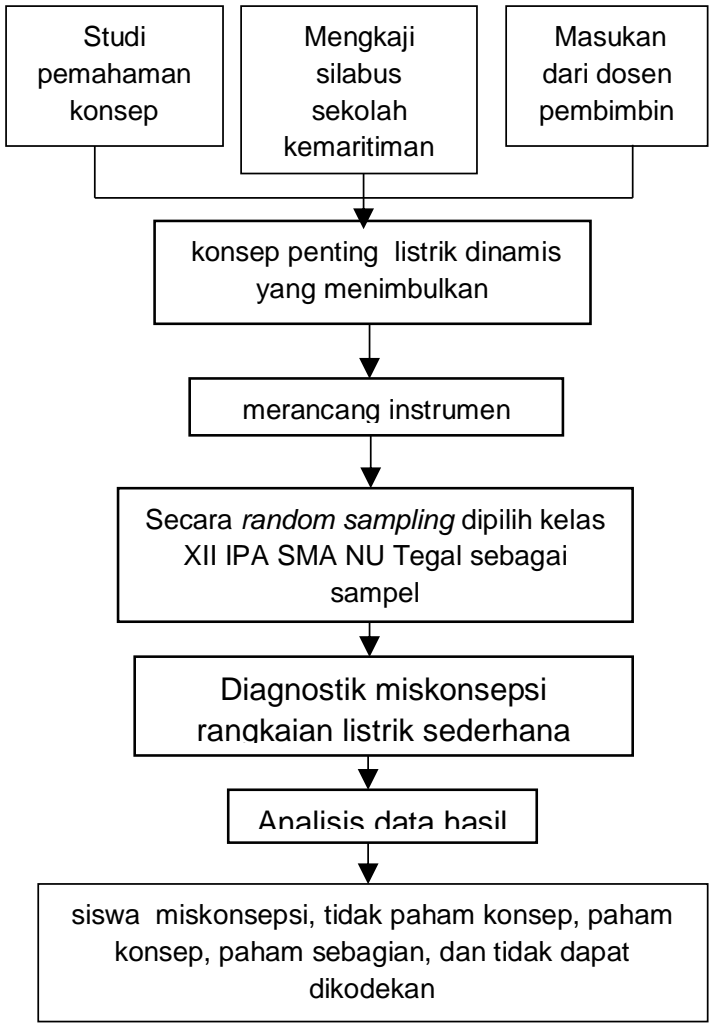

Gambar 1. Desain dan alur penelitian
Tahap penelitian yang dilakukan sebagai berikut. (1) Mengkaji referensi dan jurnal mengenai penelitian pemahaman konsep; (2) Mengkaji silabus sehingga didapat beberapa miskonsepsi pada materi fisika bab listrik dinamis; (3) Merancang instrumen soal bentuk four tier test yang dapat mendiagnosis miskonsepsi siswa; (4) Validasi oleh ahli yakni dengan dosen; (5) Uji coba instrumen untuk menentukan validitas, reliabilitas, taraf kesukaran dan daya pembeda soal; (6) Uji miskonsepsi siswa yang dilakukan kepada siswa kelas XII IPA SMA Nahdlatul Ulama. Analisis jawaban siswa terhadap Listrik dinamis four tier test untuk mendeskripsikan pamahaman konsep siswa dilakukan dengan kategori kombinasi jawaban seperti Tabel 1.

Tabel 1 Kombinasi jawaban four tier test

\begin{tabular}{|c|c|c|c|c|c|}
\hline No & Kategori & Opsi & Tingkat Keyakinan & Alasan & Tingkat Keyakinan \\
\hline 1 & Miskonsepsi & Salah & Yakin & Salah & Yakin \\
\hline 2 & Tidak paham & Salah & Yakin & Salah & Tidak Yakin \\
\hline 3 & konsep & Salah & Tidak Yakin & Salah & Yakin \\
\hline 4 & & Salah & Tidak Yakin & Salah & Tidak Yakin \\
\hline 5 & $\begin{array}{c}\text { Paham } \\
\text { Konsep dengan } \\
\text { baik }\end{array}$ & Benar & Yakin & Benar & Yakin \\
\hline 6 & Paham & Benar & Yakin & Benar & Tidak Yakin \\
\hline 7 & Konsep tetapi & Benar & Tidak Yakin & Benar & Yakin \\
\hline 8 & tidak yakin & Benar & Tidak Yakin & Benar & Tidak Yakin \\
\hline 9 & Paham & Benar & Yakin & Salah & Yakin \\
\hline 10 & Sebagian & Benar & Yakin & Salah & Tidak Yakin \\
\hline 11 & & Benar & Tidak Yakin & Salah & Yakin \\
\hline 12 & & Benar & Tidak Yakin & Salah & Tidak Yakin \\
\hline 13 & & Salah & Yakin & Benar & Yakin \\
\hline 14 & & Salah & Yakin & Benar & Tidak Yakin \\
\hline 15 & & Salah & Tidak Yakin & Benar & Yakin \\
\hline 16 & & Salah & Tidak Yakin & Benar & Tidak Yakin \\
\hline 17 & $\begin{array}{l}\text { Tidak dapat } \\
\text { dikodekan }\end{array}$ & \multicolumn{4}{|c|}{ Apabila salah satu, dua, tiga, atau semuanya tidak diisi } \\
\hline
\end{tabular}


Tingkat pertama merupakan soal pilihan ganda dengan satu kunci jawaban yang harus dipilih siswa. Tingkat ke dua merupakan tingkat keyakinan siswa dalam memilih jawaban. Tingkat ke tiga merupakan alasan siswa menjawab pertanyaan, berupa empat pilihan alasan yang telah disediakan dan satu alasan terbuka. Tingkat ke empat merupakan tingkat keyakinan siswa dalam memilih alasan (Amin, et al 2016). Keunggulan yang dimiliki tes diagnostik empat tingkat adalah guru dapat: (1) membedakan tingkat keyakinan jawaban dan tingkat keyakinan alasan yang dipilih siswa sehingga dapat menggali lebih dalam tentang kekuatan pemahaman konsep siswa, (2) mendiagnosis miskonsepsi yang dialami siswa lebih dalam, (3) menentukan bagian-bagian materi yang memerlukan penekanan lebih, (4) merencanakan pembelajaran yang lebih baik untuk membantu mengurangi miskonsepsi siswa (Amin, et al 2016).

\section{HASIL DAN PEMBAHASAN}

Dari penelitian yang telah dilakukan melalui instrumen listrik dinamis four tier test, diperoleh persentase siswa yang memahami konsep, miskonsepsi, tidak paham konsep paham sebagian ataupun error seperti Tabel 2 berikut.

Tabel 2 Persentase kategori pemahaman konsep siswa

\begin{tabular}{cccccc}
\hline No & \multicolumn{5}{c}{ Persentase siswa yang berpeluang mengalami (\%) } \\
\cline { 2 - 6 } Soal & PK & $\mathrm{M}$ & TPK & PS & $\mathrm{E}$ \\
$\mathbf{1}$ & 13,8 & 34,5 & 10,3 & 41,4 & - \\
$\mathbf{2}$ & 20,7 & 13,8 & 10,3 & 55,2 & - \\
$\mathbf{3}$ & 13,8 & 20,7 & 10,3 & 55,2 & - \\
$\mathbf{4}$ & 13,8 & 13,8 & 13,8 & 55,2 & 3,4 \\
$\mathbf{5}$ & 20,7 & 44,8 & 17,2 & 13,8 & 3,4 \\
$\mathbf{6}$ & 13,8 & 20,7 & 17,2 & 17,2 & - \\
$\mathbf{7}$ & 13,8 & 24,1 & 20,7 & 41,4 & - \\
$\mathbf{8}$ & 10,3 & 34,4 & 68,9 & 48,3 & - \\
$\mathbf{9}$ & 13,8 & 27,6 & 34,4 & 24,1 & - \\
$\mathbf{1 0}$ & 17.2 & 10,3 & 37,9 & 34,5 & - \\
$\mathbf{1 1}$ & 17,2 & 34,5 & 13,8 & 34,5 & - \\
$\mathbf{1 2}$ & 20,7 & 17,2 & 20,8 & 37,9 & 3,4 \\
$\mathbf{1 3}$ & 10,3 & 31 & 68,9 & 48,3 & 3,4 \\
\hline
\end{tabular}

Dengan: PK = Paham Konsep; $\mathrm{M}=$ Miskonsepsi; TPK = Tidak Paham Konsep; $\mathrm{PS}=$ Paham Sebagian dan $\mathrm{E}=$ Error

Berdasarkan Tabel 2, diperoleh persentase siswa berpeluang mengalami miskonsepsi terbesar pada soal nomor 5 mengenai daya listrik sebesar $44,8 \%$. Pada soal disediakan gambar 3 buah rangkaian dengan jumlah resistor sama yang tersusun secara seri, akan tetapi memiliki jumlah dan susunan baterai yang berbeda. Siswa disuruh menentukan manakah rangkaian listrik dengan daya disipasi terbesar. Daya disipasi rangkaian di tentukan kuat arus listrik total yang melalui rangkaian dan hambatan total dalam rangkaian tersebut, sehingga rangkaian dengan daya disipasi terbesar adalah rangkaian dengan susunan baterai secara seri jika jumlah dan susunan hambatan sama. Siswa terindikasi mengalami miskonsepsi dengan memilih alasan bahwa daya listrik yang terdisipasi pada rangkaian hanya dipengaruhi oleh besarnya sumber tegangan (baterai). Sehingga apabila dua buah rangkaian memiliki jumlah sumber tegangan (baterai) yang sama walaupun disusun berbeda, maka daya yang dihasilkan tetap sama besar. Sebagian siswa lainnya 
mengalami miskonsepsi dengan memilih alasan bahwa rangkaian yang memiliki susunan paralel sumber tegangan (baterai) akan menghasilkan daya disipasi lebih besar dari rangkaian dengan susunan sumber tegangan (baterai) secara seri jika jumlah sumber tegangan (baterai) sama. Siswa salah dalam memilih jawaban dan alasan jawabannya, namun mereka yakin dalam memilih jawaban tersebut sehingga dikategorikan miskonsepsi.

Persentase peluang miskonsepsi terbesar yaitu $34,5 \%$ terdapat pada soal nomor 1, 8, dan 11 mengenai rangkaian listrik sederhana, kuat arus listrik pada rangkaian tertutup, dan susunan rangkaian hambatan campuran. Soal nomor 1 menyajikan gambar sebuah lampu yang dihubungkan dengan kabel pada kutub positif baterai saja. Siswa disuruh menentukan apakah lampu akan menyala. Lampu dalam soal akan tidak akan meyala karena kabel hanya terhubung pada terminal positif baterai saja. Sedangkan syarat suatu rangkaian dapat dialiri arus listrik adalah rangkaian harus tertutup, sehingga agar lampu menyala butuh tambahan kabel penghubung antara lampu dengan terminal negatif baterai. Siswa terindikasi mengalami miskonsepsi dengan memilih alasan bahwa lampu yang terhubung baterai akan menyala walaupun hanya terhubung pada terminal positif saja. Sebagian siswa lainnya mengalami miskonsepsi dengan menganggap bahwa agar lampu menyala butuh kabel tambahan yang dihubungkan dari kutub negatif beterai ke kutub positif baterai kemudian dihubungkan ke bagian das ar bola lampu agar muatan positif bergerak menuju bola lampu.

Soal nomor 8 mengenai kuat arus listrik pada rangkaian tertutup disajikan gambar 2 buah rangkaian listrik dengan susunan berbeda. Rangkaian 1 memiliki satu hambatan, sedangkan rangkaian 2 memiliki dua hambatan yang disusun paralel. Siswa disuruh membandingkan besar kuat arus yang melalui rangkaian gambar 1 dan gambar 2. Siswa mengalami miskonsepsi dengan menganggap bahwa penambahan hambatan rangkaian secara paralel akan mengurangi kuat arus total yang mengalir pada rangkaian tertutup. Mereka juga mempuyai anggapan bahwa pada penambahan hambatan/lampu secara paralel, maka energi yang disuplai baterai akan dipakai oleh semua hambatan/lampu yang tersusun paralel tersebut, sehingga arus listrik yang mengalir akan berkurang. Sebagian siswa lainnya juga sangat yakin bahwa penambahan resistor secara paralel akan memperbesar hambatan total rangkaian.

Soal nomor 11 mengenai susunan rangkaian hambatan listrik campuran disajikan tiga buah hambaratan, dimana dua hambatan disusun secara paralel, kemudian disusun seri dengan satu hambatan lainnya. Saklar yang terhubung pada salah satu hambatan yang disusun paralel kemudian dibuka. Siswa disuruh menghitung besar hambatan total penghantar jika saklar dibuka dibandingkan sebelum saklar dibuka. Beberapa siswa terindikasi mengalami miskonsepsi dengan menganggap bahwa hambatan total setelah saklar dibuka menjadi berkurang karena jika salah satu hambatan dari rangkaian hambatan yang disusun paralel tidak berfungsi atau dihilangkan, maka hambatan total menjadi berkurang. Sebagian siswa lainnya mengalami miskonsepsi bahwa nilai hambata total tetap sama jika saklar dibuka, dan yang berubah hanyalah nilai kuat arus yang melalui rangkaian karena cabang pada rangkaian berkurang dengan dibukanya saklar.

Peluang miskonsepsi terbesar selanjutnya yaitu pada soal nomor 13 mengenai susunan seri-paralel hambatan dan sumber tegangan. Pada soal disajikan gambar dua buah rangkaian tertutup dimana rangkaian 1 berisi satu lampu dan satu baterai, sedangkan rangkaian 2 berisi dua buah baterai dan dua buah lampu yang disusun paralel. Siswa diminta untuk membandingkan nyala lampu pada susunan rangkaian gambar 1 dan gambar 2. Dari hasil jawaban siswa, diperoleh sebanyak $31 \%$ siswa mengalami miskonsepsi. Sebagian siswa terindikasi miskonsespi dengan menjawab rangkaian dengan dua lampu dan dua baterai yang tersusun paralel akan lebih redup karena penambahan baterai dan satu hambatan identik secara paralel menjadikan arus listrik rangkaian tidak berubah. Sebagian siswa lainnya mengalami 
miskonsepsi dengan menganggap bahwa penambahan hambatan secara paralel akan mengurangi besar arus listrik yang mengalir dalam rangkaian. Rangkaian dengan nyala lampu lebih redup sebenarnya adalah rangkaian 1. Hal ini disebabkan karena penambahan baterai secara paralel tidak akan mengubah tegangan rangkaian, sedangkan penambahan hambatan secara paralel akan mengurangi nilai hambatan total rangkaian sehingga arus total yang mengalir pada rangkaian 2 menjadi lebih besar.

Soal nomor 9 mengenai kuat arus listrik pada rangkaian tertutup, sebanyak 27,6\% siswa terindikasi miskonsepsi. Pada soal nomor 9 disajikan gambar sebuah rangkaian dengan dua buah hambatan identik yang disusun paralel. Siswa disuruh membandingkan besar kuat arus pada titik sebelum masuk percabangan dan pada kedua titik pada percabangan. Siswa mengalami miskonsepsi dengan menganggap bahwa pada rangkaian tertutup yang memiliki hambatan paralel, besar arus listrik sama pada setiap titik baik pada percabangan maupun diluar percabangan. Sebagian siswa lainnya mengalami miskonsepsi dengan menganggap bahwa arus listrik dihasilkan oleh kedua kutub baterai (positif dan negatif), sehingga arus listrik akan bertemu dari arah yang berlawanan.

Sebanyak $24,1 \%$ siswa juga terindikasi mengalami miskonsepi pada soal nomor 7 dengan sub bab beda potensial pada ujungujung penghantar. Dalam soal disajikan gambar sebuah rangkaian tertutup dengan sebuah baterai dan dua buah lampu/hambatan. Siswa diminta menentukan urutan nilai beda potensial dari terbesar ke terkecil.

Hasil analisis jawaban siswa, diperoleh terindikasi miskonsepsi dengan menjawab titik yang lebih dekat dengan baterai akan memiliki beda potensial lebih besar. Sebagian siswa lainnya mengalami miskonsepsi dengan menganggap pada rangkaian hambatan yang disusun seri, maka beda potensial pada setiap titik memiliki nilai yang sama besar.

Penelitian pemahaman konsep siswa dengan listrik dinamis four tier test ini juga dapat diketahui persentase siswa yang tidak paham konsep. Dari hasil analisis jawaban siswa pada tabel, diperoleh persentase terbesar siswa tidak memahami konsep terdapat pada soal nomor 8 dan 13 mengenai kuat arus pada rangkaian tertutup dan susunan seri-paralel hambatan dan sumber tegangan.

Siswa kurang memahami konsep kuat arus listrik pada susunan rangkaian hambatan baik seri, paralel, maupun campuran. Siswa belum dapat membedakan besar kuat arus total dengan besar kuat arus yang melalui masingmasing titik pada rangkaian terutama pada rangkaian yang disusun secara paralel. Siswa juga belum dapat mebedakan antara konsep arus listrik dan energi listrik yang terdisipasi pada setiap rangkaian hambatan yang disusun paralel.

Soal nomor 13 siswa belum memahami konsep kuat arus listrik pada susunan seriparalel hambatan dan sumber tegangan. Siswa tidak memahami konsep bahwa penambahan baterai secara paralel tidak mengubah gaya gerak listrik total, sedangkan penambahan hambatan secara paralel akan mengurangi nilai hambatan total dalam rangkaian.

Siswa terindikasi tidak memahami konsep lainnya sebesar $37,9 \%$ pada soal nomor 10 mengenai susunan rangkaian listrik seri. Siswa tidak memahami jika pengubahan nilai salah satu hambatan yang disusun seri akan mengubah nilai hambatan total rangkaian hambatan.

Secara umum pemahaman siswa terhadap materi listrik dinamis dapat dibuat grafik seperti Gambar 1. 


\section{Grafik Pemahaman Siswa terhadap Materi Listrik Dinamis}

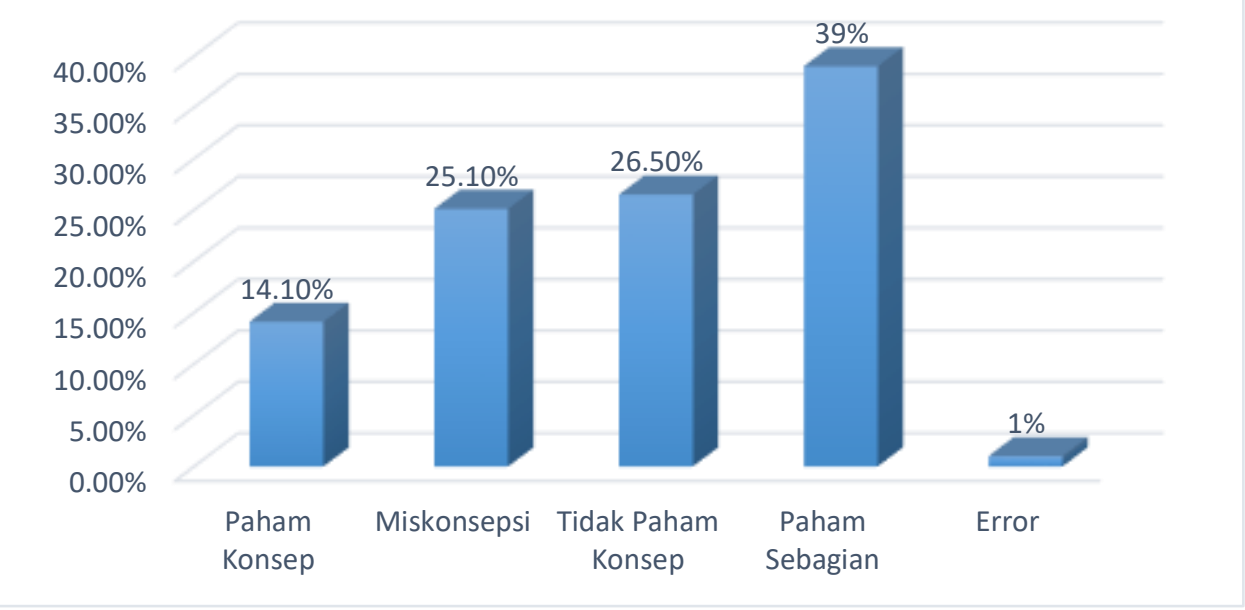

Gambar 2 Grafik pemahaman konsep siswa

Berdasarkan grafik pada Gambar 2 dapat diperoleh siswa yang dikategorikan paham konsep, miskonsepsi, tidak paham konsep, paham sebagian, dan error. Sebanyak $14,1 \%$ siswa dikategorikan memahami konsep, 25,1\% siswa termasuk dalam kategori miskonsepsi, $26,5 \%$ siswa termasuk kategori tidak paham konsep, $39 \%$ siswa paham sebagian, dan sisanya $1 \%$ siswa tidak dapat dikodekan.

Berdasarkan hasil analisis jawaban siswa dari listrik dinamis four tier test diperoleh ragam miskonsepsi siswa terhadap materi listrik dinamis sebagai berikut.

1. Sebuah lampu yang pada kutub positif baterai saja dengan menggunakan kabel akan menyala.

2. Jika hambatan listrik dalam rangkaian bertambah yaitu melalui penambahan hambatan secara seri, maka arus listrik total yang mengalir akan bernilai tetap, sehingga daya listrik pada rangkaian juga bernilai tetap.

3. Penambahan hambatan yang disusun secara seri tidak akan berpengaruh terhadap besarnya arus listrik total yang mengalir pada rangkaian tertutup.

4. Daya listrik yang terdisipasi pada rangkaian hanya dipengaruhi oleh besarnya sumber tegangan (baterai). Penambahan dan pengubahan susunan hambatan rangkaian tidak berpengaruh pada besarnya daya yang terdisipasi pada rangkaian.
5. Lampu/hambatan yang lebih dekat dengan sumber tegangan/baterai akan dialiri arus listrik yang lebih besar, sehingga nyala lampu lebih terang.

6. Arus listrik dipakai oleh lampu/hambatan yang dekat dengan baterai terlebih dahulu sehingga tersisa arus listrik lebih kecil yang mengalir pada hambatan selanjutnya.

7. Apabila antara dua titik dalam rangkaian tertutup tidak terdapat resistor/lampu, maka antara dua titik tersebut tidak akan dilalui arus listrik.

8. Beda potensial antara dua titik yang terpasang resistor dan letaknya lebih dekat dengan baterai akan memiliki beda potensial yang lebih besar.

9. Penambahan hambatan rangkaian secara paralel akan mengurangi kuat arus total yang mengalir pada rangkaian tertutup.

10.Pada penambahan hambatan secara paralel, maka energi yang disuplai baterai akan dipakai oleh semua hambatan yang tersusun paralel tersebut, sehingga arus listrik yang mengalir akan berkurang.

11.Penambahan resistor secara paralel akan memperbesar hambatan total rangkaian.

12.Pada rangkaian tertutup yang memiliki hambatan tersusun paralel, besar arus listrik yang mengalir sama besar pada setiap titik baik pada percabangan maupun diluar percabangan.

13.Arus listrik dihasilkan oleh kedua kutub 
baterai (positif dan negatif), sehingga arus listrik akan bertemu dari arah yang berlawanan.

14.Penambahan nilai resistor yang lebih dekat dengan baterai akan mengurangi kuat arus listrik yang mengalir dalam rangkaian dibandingkan dengan mengubah nilai resistor yang lebih jauh dari baterai walaupun dengan besar yang sama.

15.Pengubahan nilai resistor dalam rangkaian tidak berpengaruh pada nyala lampu karena baterai yang dipakai sama (tidak diganti).

\section{PENUTUP}

\section{Simpulan}

Berdasarkan hasil penelitian dan pembahasan diperoleh sebanyak $14,1 \%$ siswa dikategorikan memahami konsep, 25,1\% siswa termasuk dalam kategori miskonsepsi, 26,5\% siswa termasuk kategori tidak paham konsep, $39 \%$ siswa paham sebagian, dan sisanya $1 \%$ siswa tidak dapat dikodekan. Peluang miskonsepsi terbesar yaitu sebesar 44,8 \% terdapat pada materi daya listrik, dan sebesar $34,5 \%$ terdapat pada materi rangkaian listrik sederhana, kuat arus listrik pada rangkaian tertutup, dan susunan rangkaian hambatan campuran.

Miskonsepsi paling dominan yaitu daya listrik yang terdisipasi pada rangkaian hanya dipengaruhi oleh besarnya sumber tegangan (baterai). Penambahan dan pengubahan susunan hambatan rangkaian tidak berpengaruh pada besarnya daya yang terdisipasi pada rangkaian. Miskonsepsi siswa ini dipengaruhi oleh intuisi kehidupan seharihari.

\section{Saran}

Adanya penambahan kurikulum kemaritiman pada beberapa sekolah di Indonesia dimungkinkan memengaruhi pemahaman konsep siswa. Dari hasil penelitian ini, dapat dilakukan penelitian lanjutan pada sekolah kemaritiman lain di Indonesia guna mengungkap pemahaman konsep secara lebih umum dan luas pada sekolah berbasis kemaritiman.

\section{DAFTAR PUSTAKA}

Amin, N., Wiendartun, \& Samsudin, A. (2016) Analisis Instrumen Tes Diagnostik Dynamic-Fluid Conceptual Change Inventory (DFCCI) Bentuk Four-Tier Test pada Beberapa SMA di Bandung Raya. Prosiding Simposium Nasional Inovasi dan Pembelajaran Sains (SNIPS) (hal. 570574). Bandung: Universitas Pendidikan Indonesia.

Fariyani, Q., Rusilowati, A., \& Sugianto (2017) Fourtier diagnostic test to Identify Misconceptions In Geometrical Optics'. Unnes Science Educational Journal. 6(3), 1724-1729.

Fratiwi, N. J. (2017) The Transformation of Two-Tier Test Into Four Tier Test on Newton's Law Concepts. AIP Conference Proceedings. 1848: 050011-1-050011

Mardapi, D. (2012). Pengukuran, Penilaian, dan Evaluasi Pendidikan. Yogyakarta: Nuha Medika.

Papadimitriou, E., Yannis, G., \& Golias, J. (2012). Analysis of pedestrian exposure to risk in relation to crossing behavior. Transportation research record, 2299(1), 79-90.

Turgut, Ü., Gürbüz, F., \& Turgut, G. (2011). An investigation 10th grade students' misconceptions about electric current. Procedia-Social and Behavioral Sciences, 15, 1965-1971 